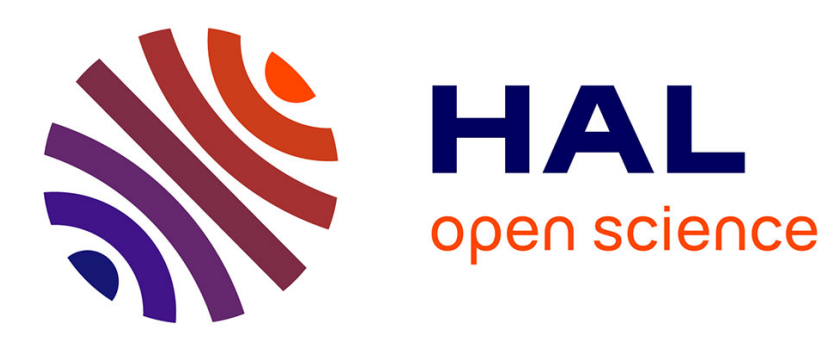

\title{
Identity and Minority Status in Two Legal Traditions
}

John Victor Tolan

\section{To cite this version:}

John Victor Tolan. Identity and Minority Status in Two Legal Traditions. Identity in the Middle Ages: Approaches from Southwestern Europe, 2021. halshs-03559615

\section{HAL Id: halshs-03559615 https://shs.hal.science/halshs-03559615}

Submitted on 7 Feb 2022

HAL is a multi-disciplinary open access archive for the deposit and dissemination of scientific research documents, whether they are published or not. The documents may come from teaching and research institutions in France or abroad, or from public or private research centers.
L'archive ouverte pluridisciplinaire HAL, est destinée au dépôt et à la diffusion de documents scientifiques de niveau recherche, publiés ou non, émanant des établissements d'enseignement et de recherche français ou étrangers, des laboratoires publics ou privés. 


\title{
CARMEN MONOGRAPHS AND STUDIES
}

\author{
Series Editors \\ Andrea Vanina Neyra, CONICET, Buenos Aires \\ Jitske Jasperse, Humboldt-Universität, Berlin \\ Kathleen Neal, Monash University \\ Alice Sullivan, University of Michigan
}

\section{Further Information and Publications}

www.arc-humanities.org/our-series/arc/cvm/ 


\section{IDENTITY IN \\ THE MIDDLE AGES}

\section{APPROACHES FROM SOUTHWESTERN EUROPE}

Edited by

FLOCEL SABATÉ

ARChumanities press 


\section{British Library Cataloguing in Publication Data}

A catalogue record for this book is available from the British Library.

\section{(C) 2021, Arc Humanities Press, Leeds}

The authors assert their moral right to be identified as the authors of their part of this work.

Permission to use brief excerpts from this work in scholarly and educational works is hereby granted provided that the source is acknowledged. Any use of material in this work that is an exception or limitation covered by Article 5 of the European Union's Copyright Directive (2001/29/EC) or would be determined to be "fair use" under Section 107 of the U.S. Copyright Act September 2010 Page 2 or that satisfies the conditions specified in Section 108 of the U.S. Copyright Act (17 USC §108, as revised by P.L. 94-553) does not require the Publisher's permission.

ISBN (print): 9781641892582

e-ISBN (PDF): 9781641892599

\section{www.arc-humanities.org}

Printed and bound in the UK (by CPI Group [UK] Ltd), USA (by Bookmasters), and elsewhere using print-on-demand technology. 


\section{CONTENTS}

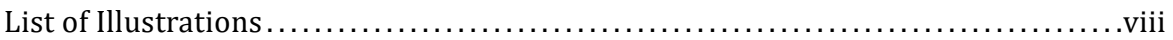

Foreword

FLOCEL SABATÉ ix

Introduction. Identity in the Middle Ages

FLOCEL SABATÉ 1

Chapter 1. Identity as a Historiographical Concept

JAUME AURELL 55

\section{PART ONE: \\ CONSTRUCTING INDIVIDUAL IDENTITY}

Chapter 2. Baptismal Names and Identity in the Early Middle Ages

IGOR S. FILIPPOV.

Chapter 3. Personal Names and Identity in the Iberian Peninsula

MOISÉS SELFA

Chapter 4. Gender and Feminine Identity in the Middle Ages

ANA MARIA S. A. RODRIGUES

Chapter 5. Identity, Memory, and Autobiographical Writing

in Twelfth- and Thirteenth-Century French Literature

MERITXELL SIMÓ.

Chapter 6. Why Ibn Ḥazm became a Zāhirī: Law, Charisma, and the Court

MARIBEL FIERRO.

Chapter 7. Eunuchs in the Emirate of al-Andalus

CRISTINA DE LA PUENTE. 


\section{PART TWO: SOCIAL IDENTITIES}

Chapter 8. Identity and Minority Status in Two Legal Traditions

JOHN TOLAN 203

Chapter 9. Medieval Peasants' Image of Themselves in Relation to the Seigneurial Regime

PAUL FREEDMAN

Chapter 10. Chivalric Identity: Arms and Armour, Text and Context

NOEL FALLOWS

Chapter 11. The Emergence of a Bourgeois Urban Identity:

Late Medieval Catalonia

FLOCEL SABATÉ

Chapter 12. Culture and Marks of Identity among the

Social Outcasts and Criminals of Late Medieval Spain

RICARDO CóRDOBA. 261

\section{PART THREE: IDENTITY AND TERRITORY}

Chapter 13. Identity and the Rural Parish in Medieval Iberia

RAQUEL TORRES JIMÉNEZ

Chapter 14. The Breakdown of Vertical Solidarity

among the Late Medieval Basque Nobility

JOSÉ RAMÓN DÍAZ DE DURANA and ARSENIO DACOSTA.

Chapter 15. Identity-Making Discourses in the Kingdom of Sardinia and Corsica and the Giudicato of Arborea

LUCIANO GALLINARI.

Chapter 16. The Crown of Aragon and the Regnum Sardiniae et Corsicae in the Fourteenth Century: Comparing Institutional Identities 


\section{PART FOUR: REPRESENTATIVE COLLECTIVE IDENTITIES}

Chapter 17. Political Identity and Patrician Power in the City of Burgos during the Fifteenth Century

Chapter 18. Fiscal Attitudes and Practices and the Construction of Identity in Late Medieval Cuenca

JOSÉ ANTONIO JARA

Chapter 19. Constructing an Identity: Urban Centres and their Relationship with the Crown of Navarre, 1300-1500

Chapter 20. Celebration of Identity in Thirteenth- to Fifteenth-Century Florence, Milan, and Venice

PAOLA VENTRONE

Chapter 21. Local and "State" Identities in Cities of

Fifteenth- and Sixteenth-Century Northern and Central Italy 


\section{LIST OF ILLUSTRATIONS}

\section{Figures}

Figure 13.1: Campo de Calatrava. ................................. 276

Figure 18.1: Graph of the Growth and Distribution of Expenditure............ 377

\section{Tables}

Table 19.1: Good Towns in the order in which they were granted

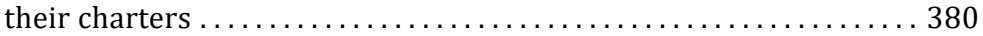

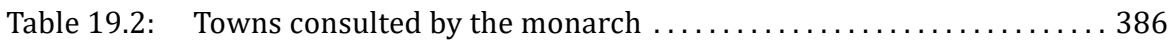

Table 19.3: $\quad$ Number of Judges appointed to the Good Towns (1254, July) . . . . . . 391

Table 19.4: Fraternity of Good Towns called to supervise the governor appointed by the Parliament (1254, July 27) .......... 392

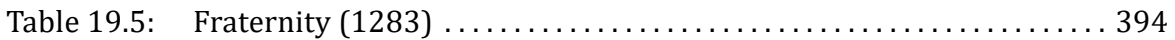

Table 19.6: Sequence of assemblies related to the Good Towns ............. 396

Table 19.7: $\quad$ Assemblies and the Fraternity of Good Towns $\ldots \ldots \ldots \ldots \ldots \ldots 401$

Table 19.8: Delegations from the Good Towns to Paris for the swearing-in ceremony. 404

Table 19.9: Agreements from the Meeting held by the Good Towns (1328, April 16). 


\section{FOREWORD}

\section{FLOCEL SABATÉ}

LET ME BEGIN by using this foreword to explain briefly the aims and ideas that inspire the present book, both through a substantial introduction analyzing what we understand by identity in the Middle Ages, and through specific studies that deepen our knowledge of relevant aspects of a topic of great political importance today.

The "power of identity," to use the title of the second volume of the study of "The Informacion Age" by sociologist Manuel Castells, ${ }^{1}$ has been strongly emphasized during the last decades. Different studies have been devoted to analyze the search for identity in our plural societies, the intertwining of various types and levels of identity, the risks around identity conflicts and, in any case, the rise of identity, with its different meanings, in the articulation of current society. ${ }^{2}$ Too often history has been used to justify real, recreated, or imagined identities. This is not our aim. Noticing the search for identity in individuals and collectivities throughout history, and looking for new perspectives to reach the core of precedent societies, we adopt identity as an object of analysis, that is, as a challenge to open new ways and tools for historians' work.

Certainly, this book places identity at the centre of a project to better understand medieval society. By exploring the multiplicity of personal identities, the ways these were expressed within particular social structures (such as feudalism), and their evolution into formal expressions of collective identity (municipalities, guilds, nations, and so on) we can shed new light on the Middle Ages. A specific legacy of such developments was that by the end of the Middle Ages, a different sense of collective identities, supported by the late medieval socio-economic structure, backed in law and by theological, philosophical, and political thought, defined society. What is more, social structures coalesced across diverse elements, including language, group solidarities, and a set of assumed values.

We understand that identity occupied that central position in defining medieval society with two allied concepts: memory and ideology. The former served to ground identity, while the latter consolidated a coherent common memory and identity. For this reason, this book has two companions devoted to each of these concepts. We think that

I Manuel Castells, The Information Age. II The Power of Identity (Cambridge, MA), 1997.

2 Among others: Will Kymlicka, Multicultural Critizenship: A Liberal Theory of Minority Rights (Oxford, 1996); Gerd Baumann, The Multicultural Riddle (New York, London, 1999); Mario Carretero, Documentos de identidad. La construcción de la memoria histórica en un mundo global (Buenos Aires, 2007); Gérard Noiriel, À quoi sert l'identité 'national' (Paris, 2007); Chatterje Partha, La nación en tiempo heterogéneo y otros estudios subalternos (Buenos Aires, 2008); Hermenegildo Fernandes, Isabel Castro Henriques, José de Silva Horta, Sergio Campos Matos, ed., Naçâo e identidades. Portugal, os Portugueses e os Outros (Lisbon, 2009); Francesco Remotti, L'ossessione identitaria (Bari, 2010); Diego Bermejo, ed., La identidad en sociedades plurales (Barcelona, 2011); Zygmunt Bauman, Oltre le nazioni. L'Europa tra sovranità e solidarità (Bari, 2012); Francesco Remoti, Contro l'identità (Bari, 2012). 
this is a good path for approaching an understanding of the values and interpretative axes that informed the thinking of women and men in the Middle Ages. This holistic vision requires interdisciplinary approaches, as opposed to academic compartmentalization of history, art history, and the study of languages and literatures.

With this in mind, we present a work structured in a particular way, beginning with a long introductory chapter (by Flocel Sabaté) on medieval identity. This introduction does not aim to map out identity in its entirety, but rather to provide insights into key aspects of the medieval understandings of identity. It frames ensuing discussions by exploring the various ways in which individuals affirmed their notion of identity, always involving the individual's relation to a group with which they felt solidarity. A sense of one's own identity involves notions of otherness, and therefore involves both external perceptions and an internal sensibility, and relates to ideas concerning "representativity" (the conditions of a representation, from the French word représentativité). In the Middle Ages, this generated various discourses and cultural displays in order to support particular identities, which generated specific collectively-held memories and descriptions of teleological destiny, associated with particular societies and territories.

Having established an overview of identity in the Middle Ages, the introduction is followed by twenty-one focused chapters by leading researchers which delve deeper into specific fields. They share a concern for illuminating medieval thought, focusing on concrete cases, and prioritizing examples from southern Europe, a region with a large amount of documentation, but which to date has occupied a relatively minor position in the overall spread of research into the Middle Ages. We acknowledge this emphasis in the title of this book, Identity in the Middle Ages: Approaches from Southwestern Europe, which is offered as a means of enriching study of the Middle Ages.

The resulting chapters are organized into four domains representing the four parts in the book, offering, in our view, useful ways of exploring identity.

The overall concept is part of a long historiographical journey, linked particularly to the return of cultural history in the search for new perspectives with which to develop historical research. That is why we invited Jaume Aurell to launch this volume with an overview of this historiographical development.

Having provided the historiographical framework, we delve deeper into the function of identity in the Middle Ages through four blocks we consider axial: constructing individual identity; social identity; identity and territory; and forms of collective identity.

Constructing individual identity is, in fact, one of the vital contributions of the Middle Ages, by defining the individual elements that allow a person to define himself or herself, and this continues today. For instance, adopting a name seems crucial in the perception and assumption of individuality. Igor Filippov provides here a fascinating study of baptismal names and self-identification in the Early Middle Ages. Moisés Selfa goes on to show how names reflect a specific identity in a particular social context. Ana Maria S.

A. Rodrigues then shows how the personal identity that one accepts is fundamentally linked to the cultural model of gender. She presents varying degrees of acceptance, by different women, of specific ideals of femininities. At the same time, the awareness of one's individuality, the struggle between individual and group, was evident for instance in twelfth-century literature, where shared memories might include autobiographical 
expressions, as Meritxell Simó shows. The assumption of an identity means the integration of a memory, and Maribel Fierro shows, in Islamic society, how this implies specific religious and legal values. Society supplies models into which individuality can fit, but it can also offer space for exceptions, as in the case of eunuchs in Islamic society, as shown in the chapter by Cristina de la Puente.

People were never alone in the Middle Ages. They formed part of a group in which they felt integrated and protected. We therefore need to consider identity in terms of the social group. Given that the rules for social order were based on the majority religion, it was necessary to adopt specific status for minorities when Christians, Jews and Muslims shared a same space, as John Tolan analyzes. At the same time, social identity requires us to understand that appropriate models were generated for each social group. Paul H. Freedman shows us how a specific image of the peasant was created in line with the values of medieval society, and accepted by the members of that social group. At the same time, at the other social extreme, a clear chivalric identity was formulated, well enough assumed to be widely reflected in contemporary texts, as Noel Fallows demonstrates. And Flocel Sabaté sketches how the Late Middle Ages supplied the economic, ideological, and cultural framework that gave rise to a specifically bourgeois identity. Social order was achieved by combining these units of collective identity. Conversely, we see these marks of identity in social outcasts in the chapter by Ricardo Córdoba that concludes the second part of this volume.

Human activity takes place in a determined space, over which mutual influence is developed. Strong relations between people, territory, and identity arise almost naturally. Hence the third part of this book focuses on identity and territory at different levels: firstly, in the smaller space in which everyday life happens, as Raquel Torres shows when analyzing how medieval parishes supported individuals in forming a local community. We see another field for social identity within the lordships, a setting in which José Ramon Díaz de Durana and Arsenio Dacosta show us the rise and consolidation of factions (bandos) from lineage, with their solidarity connections. They were a powerful form of mutual identity, which became very complex and affected all relations, either with other powers or the sovereign, and determined the management of the territory and society. Another very different scenario is derived from the political will to promote identification between territory, population, and certain rulers. This led to interesting discourses in which a common identity tried to fashion a specific memory, as Luciano Gallinari shows for Sardinia. Also in Sardinia, Alessandra Cioppi presents the changes it underwent after its incorporation into the Crown of Aragon: the shaping of a specific identity through the implantation of a particular institutional model.

Finally, the Late Middle Ages furnished identities based on representativeness, so much so that it is one of the great legacies of medieval society. The rise of the urban patriciate was accompanied by the promotion of a specific identification between the ruling elite, municipal government, and city, as Yolanda Guerrero demonstrates. The increasing assertiveness of cities gave them a dominant position over the surrounding territory and the ability to manage their own resources, not least through taxation. José Antonio Jara shows us how a city could portray a unifying discourse to reinforce its dominant position, which in turn meant the generation of a shared identity. Urban 
power not only assumed a representativeness with which it could address the sovereign on behalf of the municipality, but this in turn affected the profile of sovereignty itself. Thus, urban identity helped model a specific definition of the country, apart from the sovereign, and became a counterpoint in defining a duality between the country and the monarch (a distinction, as Eloísa Ramírez presents, in the case of Navarre, that came to be made between the Kingdom proper and the King). In this framework, the construction of an identity for citizenship needed specific rituals, festivals, and symbols. Shared urban self-expression facilitated social cohesion within a common identity, as outlined in Paola Ventrone's chapter. The cities then went on to strengthen an identity based on their own social cohesion and projected this over their hinterlands. As a result, urban identity could adopt a social, political, and even the sense of being a "state," as Giorgio Chittolini shows from cases in central and northern Italy.

These are the various of lines of enquiry on the theme of identity in the Middle Ages that have occupied the work of the Consolidated Medieval Studies Research Group "Space, Power and Culture," based at the University of Lleida, especially through the research project Identity, Memory and Ideology in the Middle Ages (HAR2009-08598/ HIST) financed by the Spanish government, to link the study of identity, memory, and ideology in the Middle Ages. It was a challenge taken up from an earlier project: Historical Memory: Images of the Middle Ages. The Real World and Recreated Space (BHA2003-00523). Both projects aimed to advance new perspectives on the study of the Middle Ages. Close collaboration with the Institute for Research into Identities and Society (IRIS), based at the University of Lleida between 2009 and 2013, worked towards the same objective. The work of its research team and numerous wider scholarly meetings held at Lleida helped to consolidate these objectives. This was also made possible with the support of various complementary projects financed by the Spanish Ministry of Research: Identities (HAR2008-02766-E/HIST); Sacred Voices (FFI2008-03031-E/ FILO); Identities: A Definition (HAR2010-10915-E/HIST); Identities: Definition and Context: A Multidisciplinary Approach (HAR2010-10803-E/HIST); and Hybrid Identities: An Interdisciplinary Vision of the Social World (HAR2011-13084-E).

Thanks to these projects, various co-authored books on the subject of identity in the Middle Ages have appeared, bringing together the work of leading researchers from varied fields of study related to the Middle Ages. ${ }^{3}$ This book builds on prior studies and is, to a large extent, a culmination of the work done previously. In producing, selecting, revising, and bringing to fruition the final texts in this volume, the research projects financed by the Spanish government Feelings, Emotion, and Expressivity (HAR-2016-

3 Publications involving the present volume editor include: Flocel Sabaté, ed., Identitats (Lleida, 2012); Flocel Sabaté and Christian Guilleré, eds., Morphologie urbaine et identité sociale dans la ville médiévale hispanique (incorrectly published as Morphologie et identité sociale dans la ville médiévale hispanique) (Chambéry, 2012); Flocel Sabaté, ed., L'Edat Mitjana: món real i espai imaginat (Catarroja, 2012); Xavier Terrado and Flocel Sabaté, eds., Les veus del sagrat (Lleida, 2014); Flocel Sabaté, ed., Identities on the Move (Bern, 2014); Flocel Sabaté, ed., Hybrid Identities (Bern, 2014); Flocel Sabaté, ed., Perverse Identities: Identities in Conflict (Bern, 2015); Flocel Sabaté, ed., Conditioned Identities: Wished-for and Unwished-for Identities (Bern, 2015); and Flocel Sabaté, ed., Medieval Urban Identity: Health, Economy and Regulation (Newcastle, 2015). 
75028-P) and Power Experienced in the Late Middle Ages: Perception, Representativeness and Expressiveness in the Management and Reception of Power (PID2019-104085GBI00), the ICREA-Academia award to Flocel Sabaté (2016-2020), and supported by Arc Humanities Press's peer review and pre-press processes, have all been instrumental, for which we are sincerely grateful. We hope that this volume, together with Ideology in the Middle Ages: Approaches from Southwestern Europe and Memory in the Middle Ages: Approaches from Southwestern Europe will illuminate in new depth the links between identity, ideology, and memory in the Middle Ages and open new pathways to how we interrogate and understand the Middle Ages. ${ }^{4}$

4 Translations into English are generally provided as close to the original text as possible, and the original text and edited source is provided in the notes. We follow the press's practice as a worldwide publisher in retaining native forms as far as possible. Abbreviations to sources from the Monumenta Germaniae Historica (hereafter MGH) follow the guidelines of the Deutsches Archiv journal: www.mgh.de/fileadmin/Downloads/pdf/DA-Siglenverzeichnis.pdf. 



\title{
Chapter 8
}

\section{IDENTITY AND MINORITY STATUS IN TWO LEGALTRADITIONS}

\author{
JOHN TOLAN
}

IN THE MIDDLE Ages, from Baghdad to Barcelona, we find many minority religious communities: all over the Muslim world, Jews and Christians lived as dhimmis, protected and subordinated minorities. In Byzantium and all over Latin Europe, Jewish communities lived in a society which alternated between tolerance and persecution of them. Some Muslims lived in Christian kingdoms (in Sicily, in the Latin Orient, and in certain Christian Hispanic kingdoms). The Muslim and Christian sovereigns of the Middle Ages claimed that their power derived from God. Caliphs, emperors, popes, and kings used religious arguments to reinforce and justify their power.

These religious ideologies expressed the inferiority of all those people who did not proclaim the majority faiths. This religious inferiority consisted of a legal and social subordination but, at the same time, we can find instructions for tolerance towards members of different religions within society in the Christian and Muslim traditions. How can we define the position of the minority in these societies? ${ }^{1}$

I would like to look at two examples in order to explain how these jurists from the minority communities perceived their subordination. First, the point of view of a Muslim Mufti on whether it is legal for Muslims to reside in Norman Sicily. The second example concerns the view of Pope Gregory IX and his confessor, the canonist Raymond of Penyafort, on legal problems of Christians residing in Tūnis during the thirteenth century.

First, let us focus on the Sicilian question. Sicily was conquered by the Normans (1061-1091) partly through alliances with the Muslim Qaids who lived on the island. There were many Muslims in Sicily during the twelfth century: farmers, soldiers, but also many important figures in the court of the king (administrators, officials). ${ }^{2}$ The Andalusian traveller Ibn Jubayr (there in 1185) has left us a striking description. ${ }^{3}$

The document we are interested in is a fatwa, a juridical consultation in which a question is submitted to a mufti, who gives his opinion based on religious and legal

I For more details on this theme and the bibliography, see John Tolan, "The Social Inferiority of Religious Minorities. Dhimmis and Mudejars," in Europe and Islam. Fifteen Centuries of History, ed. Henry Laurens, John Tolan and Gilles Veinstein (Princeton, 2013), 49-69.

2 See Alexander Metcalfe, Muslims and Christians in Norman Sicily. Arabic Speakers and the End of Islam (London, 2005).

3 Ibn Jubayr, Rihla, the Travels of Ibn Jubayr Edited from a Manuscript in the University Library of Leyden, ed. William Wright and Michael Johan De Goeje (Frankfurt-am-Main, 1994).

John Tolan (john.tolan@univ-nantes.fr) is Professor of Medieval History at the Université de Nantes, France.

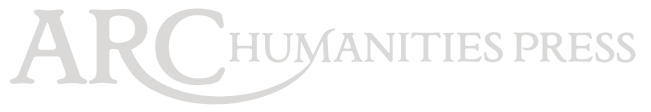


sources (and including the opinions of other scholars before him). In the Maghreb, the Malikite legal school prevailed. Al-Wansharisi (fl. sixteenth century) assembled a large collection of fatwas especially from the Andalusian and Maghrebi muftis. Al-Wansharisi included different fatwas by Al-Mazari, who was active in Mahdiyya (in modern Tunisia) and died in 1141. This is everything we know about him except that his kunya (Mazari) would indicate that he or his family were originally from the city of Mazara on Sicily. This could explain his interest in the question put to him. ${ }^{4}$

At the beginning of the fatwa, someone (we do not know who) says that someone went to see Al-Mazari to ask him the following question: "should we declare admissible, or reject any judgments from Sicily and pronounced by its qadi, as well as the depositions of sworn witnesses, knowing that they are imposed by necessity and that we could not establish whether their authors reside under the authority of infidels willingly or under duress." ${ }^{5}$ The occupation of Sicily by the "infidels" caused many legal problems, in particular concerning the legitimacy of the judgments and testimonies produced by the Muslims under non-Muslim authority. If we judge that the Muslim testimonies and the judgments of the qadi are not legitimate, we remove the foundation of the legal system of the Muslim community on the island, eliminating the possibility of a life in line with the principles of Islam.

Al-Mazari discerns two points in his answer: "the first one concerns the [person] of the qadi as well as his valid opinions considered on the integrity perspective, from the moment he resides in an enemy territory (dâr al-harb) and under the authority of the infidels, which is not allowed. The second one is connected to the designation because he is nominated by the infidel." ${ }^{16}$ So, Al-Mazari states that Muslims are not allowed to reside in the dâr al-harb, which suggests the Muslims on the island were in an irregular situation. However, there were exceptions to this rule that allowed most (not all) of the Muslims to reside on the island.

Indeed, when Al-Mazari answers the first question, he offers different reasons for a Muslim to live in infidel lands. First of all, he points out that "if the person concerned resides in an enemy country for compelling reasons, there would be nothing that could

4 I follow the French translation of this fatwa of Abdel Majid Turki, "Consultation juridique d'alImam al-Mâzarî sur le cas des musulmans vivant en Sicile sous l'autorité des Normands," Mélanges de l'université Saint-Joseph 50, no. 2 (1984): 691-704. For this fatwa, see also Sarah Davis-Secord, "Muslims in Norman Sicily. The Evidence of Imam al-Mazari's Fatwas," Mediterranean Studies 16 (2007): 46-66; John Tolan, Les Relations entre les pays d'Islam et le monde latin du milieu du Xème siècle au milieu du XIIIème siècle (Paris, 2000), 152-56.

5 “Doit-on déclarer recevables, ou bien les récuser, tout jugement en provenance de Sicile [et prononcé] par son qâdî, ainsi que les dépositions de ses témoins assermentés, tout en sachant qu'ils sont imposés para la nécessité et qu'on ne peut établir si leurs auteurs resident sous l'autorité des infidèles de plain gré ou sous la contrainte." Cited from Majid Turki, "Consultation juridique d'alImam al-Mâzarî," 152-56.

6 “Le premier touche à [la personne du] qâdî, ainsi qu’à ses avis fondés, considerée sur le plan de la probité, du moment qu'il réside en territoire ennemi ('dâr al-harb') et sous l'autorité des infidèles, chose qui n'est point permise. Le second s'attache à l'investiture, puisqu'il est investí par l'infidèle." Cited from Majid Turki, “Consultation juridique d'al-Imam al-Mâzarî,” 152-56. 
undermine his integrity." ${ }^{\text {"7 }}$ So, where there is obligation and no possibility of fleeing the island to reach Muslim territory, logically one could not reproach the Muslims for living on infidel territory. This is a principle also recognized by those jurists hostile to the residence of Muslims in infidel lands (even if the perception of what constitutes "a compelling reason" changes from one jurist to another). ${ }^{8}$

Al-Mazari goes further: "it is the same if a person does so of their own free will overlooking the judgment in force. In fact, nothing obliges them to take heed of this chapter of [legal] knowledge, so that their [alleged] ignorance would not undermine their integrity". Moreover, he affirms that if one misinterprets the law by declaring the legality of their stay in an infidel land, it would be an excusable error, because it does not compromise the integrity of the person who resides in infidel territory in a theoretically illegal way.

He has not finished. If this person "correctly interprets the law in such a way that he justifies his residence in an enemy territory with the hope of seizing it from the hands [of the occupants] and returning it to Islam and furthermore, with the hope of putting the infidels on the right path or at least diverting them from their heresy." ${ }^{10}$ So, all Sicilian Muslims who hope to see the island under the rule of a Muslim prince or to divert the Christians from their worst errors are permitted to live in infidel territory. It is difficult indeed to imagine a Sicilian Muslim who was not included in these different exceptions to the prohibitions on residence in infidel territory.

Certainly, Al-Mazari states that if someone "acts in ignorance of the law or knowingly turns away from any efforts of interpretation, there would be a reason to challenge his integrity." ${ }^{11}$ He introduced some doubts on the legitimacy of travelling to infidel territory in order to trade, noting that the Malikite jurists have different opinions about this and that "the greatest divergences have appeared in this respect when interpreting the Mudawwana" by Sahnun (d. 854). He expressed similar doubts in other fatwas regarding trade between Sicily and Ifriqiya. ${ }^{12}$

7 "Si cette personne en question réside en pays ennemi pour une raison impérieuse, il n'y a là rient qui puisse porte atteinte à sa probité." Cited from Majid Turki, "Consultation juridique d'al-Imam al-Mâzarî," 152-56.

8 Kathryn Miller, Guardians of Islam. Religious Authority and Muslim Communities of Late Medieval Spain (New York, 2008), 22-43.

9 "Il en est de même si elle le fait de son proper gré, tout en ignorant le jugement en vigueur ou tout en croyant au caractère permis de son acte. En effet, rient ne l'oblige à prendre connaissance de ce chapitre du savoir [juridique], au point que son ignorance [supposée] ne porterait pas atteinte à sa probité." Cited from Majid Turki, “Consultation juridique d'al-Imam al-Mâzarî," 152-56.

10 "Interprète correctament la loi, de sorte qu'elle justifie sa résidence en territoire ennemi par l'espoir de l'arracher d'entre les mains [des ocupants] et de le restituir à l'islam, ou de pervenir à mettre les infidèles sur la bonne voie, ou, du moins, à les détourner d'une hérésie quelconque." Cited from Majid Turki, “Consultation juridique d'al-Imam al-Mâzarî,” 152-56.

I I "Agit en méconnaissance de la loi, ou en se détournant sciemment de tout effort d'interprétation, il y a certainement là un motif d'atteinte à la probité." Cited from Majid Turki, "Consultation juridique d'al-Imam al-Mâzarî," 152-56.

12 Sara Davis-Secord, "Muslims in Norman Sicily. The Evidence of Imām al-Māzarī's Fātwas," Mediterranean Studies 16 (2007): 46-66. 
Al-Mazari concluded this matter by affirming that "tolerating his personal reasons must be the attitude to be adopted towards anyone whose probity is evident, but also whose purpose for staying in enemy territory raises suspicion. The majority of the previous suppositions plead for this tolerance and it is hardly possible to reject them all except one."13 This is a remarkable example of ijtihad (the reinterpretation of Islamic law to adapt it to new situations). Al-Mazari started with the principle that residence in an infidel land is prohibited and later (through a series of "exceptions") authorizes it for almost every Sicilian Muslim. Then, the mufti focused on the second question: the legitimacy of the qadi and other Muslim officials nominated by the Christian king and his officials in Sicily.

As regards the second matter, that is the investiture granted by the infidel to the qadis, notaries, trustees, and others, it is a fact that we have to protect people from each other, so much so that a certain disciple of the [Mâlikite] school claims to establish this obligation rationally. The author of the Mudawwana established the provisional legality guaranteed by the leaders of any place, in the absence of a prince [sultân] and this for fear of not being able to treat urgent cases in a timely manner. The designation granted by the infidel to these qadis, either to meet a compelling need or to satisfy the demand of the litigants, does not in any way affect the judgments which thus retain their enforceability as if he had been designated by a Muslim prince. ${ }^{14}$

In other words, al-Mazari considered that Sicily was in a sort of interregnum. In the past, Sicily had a Muslim sultan and (insh'Allah) it would have it again. Muslim officials had to manage the affairs of the community at such times. The legitimacy of the qadi derives from the justice of his judgments. It does not depend on whether he is appointed by an infidel. No legitimacy is recognized in the Christian king.

This is the opinion of one mufti. Others, on the contrary, affirmed that every Muslim had to leave a territory conquered by the infidel as soon as possible (in particular, some Maghrebi Malikite muftis at the end of the Middle Ages concerning Muslims under Christian authority in Spain). At the same time, others stated that staying after the con-

13 "Tolérer ses raisons personnelles doit être l'attitude de principi à adoptar envers toute personne dont la probité est évidente, mais dont le but du séjour en territoire ennemi prête néanmoins à suspicion. C'est que la grande majorité de suppositions précédentes plaident pour cette tolérance et il n'est guère possible de les repousser toutes à l'exclusion d'une seule." Cited from Majid Turki, "Consultation juridique d'al-Imam al-Mâzarî," 152-56.

14 “Pour ce qui est du second point soulevé, c'est-à-dire l'investiture accordée par l'infidèle aux qâdîs, notaires, syndics et autres [détenteurs de charges honorables], il est un fait qu'on doit impérativement protéger les gens, les uns contre les autres, tant et si bien qu'un certain disciple de l'école [mâlikite] prétend fonder rationnellement cette obligation. L'auteur de la Mudawwana établit la légalité de tout intérim assuré par les notabilités d'un lieu quelconque, en l'absence du prince [sultân], et ce de peur de ne pouvoir traiter un cas d'urgence dans les délais prescrits. L'investiture accordée par l'infidèle à ce qâdî probe, soit pour répondre à un besoin impérieux, soit pour satisfaire la demande des justiciables, ne porte nullement atteinte à des jugements qui gardent de la sorte leur caractère exécutoire, tout comme s'il avait été investi par un prince musulman." Cited from Majid Turki, “Consultation juridique d'al-Imam al-Mâzarî," 152-56 
quest and thereby maintaining a Muslim presence was a praise-worthy act. This was the case of the Hanbalite jurists during the Mongol conquest. ${ }^{15}$

What about the Christians who lived in a Muslim country? By way of example, let us look at a Latin text concerning the European Christians living in Muslim lands, and, more specifically, those who lived in Tūnis during the thirteenth century. On 19 January 1235, Raymond of Penyafort, confessor of Pope Gregory IX, wrote a letter to a Dominican prior and a Franciscan minister "in the kingdom of Tūnis." The two friars had written to the pope to ask him forty questions concerning their mission with the Christians living in Tūnis. The answers were dictated to Raymond by the Pope. Questions and answers have been preserved in a text called the Responsiones ad dubitabilia circa communicationem Christianorum cum sarracenis. The questions concern the legality of a series of practices, be it the sale of nails to Muslims or the clandestine baptism of their children. ${ }^{16}$

This text presents a unique perspective on the Christian community of Tūnis and the pope's response concerning the problems posed by the residence of Christians in Muslim lands. It shows the important activity of the merchants here (particularly Italians and Catalans), placed in the context of pontifical prohibitions on trade of certain goods. We see that some merchants transgressed these bans without worrying too much (Genoese selling ships, for example). Others clearly wanted to know which types of trade were legal. Moreover, this text offers us an unusual view of the European community of Tūnis, where not only Italian and Catalan merchants meet, but also mercenaries, crusaders, fugitives, captives, and pilgrims. In particular, there were a number of marginal people who rarely appear in Arabic or Latin documentation: renegades, slaves, converts, mixed couples.

Here, our goal is not to analyze this document in detail, much of which concerns the legality of some types of trade (since the Third and Fourth Lateran Councils had forbidden the sale of weapons, iron, and wood to "Saracens"). We examine some passages that deal with problems of conversion and mixed families.

In their eighth question, the friars observe with dissatisfaction that certain Christians pledged to the Saracens some men and women among their servants:

Also, whether are excommunicated those Christians, knights, or others, who, having commerce with Saracens, pawn or mortgage to Saracens men or women from among their

15 Khaled Abou El Fadl, "Islamic Law and Muslim Minorities: The Juristic Discourse on Muslim Minorities from the Second/Eighth to the Eleventh/Seventeenth Centuries," in Islamic Law and Society 1 (1994): 141-187; Kathryn Miller, Guardians of Islam. Religious Authority and Muslim Communities of Late Medieval Spain (New York, 2008), 22-43.

16 John Tolan, ed. and trans., "Ramon de Penyafort's Responses to Questions Concerning Relations between Christians and Saracens: Critical Edition and Translation," in HAL Archives Ouvertes, accessed January 30, 2018, https://hal.archives-ouvertes.fr/hal-00761257. About this text, see also John Tolan, "Taking Gratian to Africa: Raymond de Penyafort's Legal Advice to the Dominicans and Franciscans in Tunis," in A Faithful Sea. The Religious Cultures of the Mediterranean, 1200-1700, ed. Adnan Husain and Katherine Fleming (Oxford, 2007), 47-63; John Tolan, "Marchands, mercenaires et captifs. le statut légal des chrétiens latins en terre d'islam selon le juriste canonique Ramon de Penyafort (XIIIe s.)," in Minorités et régulations sociales en Méditerranée médievale, ed. Stéphane Boisselier, François Clement, and John Tolan (Rennes, 2010).

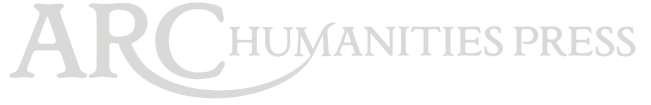


own servants, compelled by necessity. In particular, in those numerous cases when they know that they will not be able to redeem those whom they pawn. It often occurs that those who are pawned in this way, especially the boys and girls, later become Saracensand if they later are reclaimed, they are not returned. ${ }^{17}$

It seems that some indebted Christians, particularly knights, gave to their Muslim creditors men and women from among their households as security for their debts or other obligations (maybe military). The friars are upset with this pawning of human beings because of the spiritual risk this entails. We imagine that some of these Christians remained slaves to their new masters (if their old masters did not settle their debts). The friars care about these youths and fear they will end up converting to Islam. The pope's response is that this practice is a deadly sin, but at the same time does not entail excommunication.

Generally, conversion in Tūnis can be in only one direction: to Islam. One passage is about Christians who secretly attended mass at night "out of fear of the Saracens" (§16). This fear can perhaps be explained by the fact that these would be Christians converted to Islam and surreptitiously back to Christianity. Only one passage is about the baptism of Muslims. The friars point out that certain Christian servants or slaves take care of Muslim children. These servants ask the friars if they had to baptize these children secretly unbeknownst to their parents, thus if they died before the age of discretion, they would be saved. The Pope answers "let them be baptized." So, we can presume that a number of Muslim children in Tūnis in the thirteenth century were secretly baptized by their Christian nannies.

One of the main concerns of the Franciscan and Dominican ministers was the apostasy of some Christians in Tunnis and their relationships with the members of their families who remained Christians. As can be seen from other sources, these situations were habitual. The Hafsid sultans had European concubines, bought in slave markets or received as gifts. Undoubtedly, some of these converted to Islam. As regards mercenaries, most of them did not convert, though others converted to Islam. Among the translators, key actors in trade and diplomacy, were Europeans that prolonged their stay in Tūnis. Undoubtedly, some of them converted to Islam and married Muslim women.

This raises the delicate question of the relationship between Christians and their relatives converted to Islam: ${ }^{18}$

Also, there are some who were once Christians and then became Saracens, some while they were minors, others as adults; some of them are free, others captives. Since they all

17 "Item, utrum sint excommunicati milites christiani uel allii, qui conuersantes cum sarracenis, obligant uel impignorant uiros uel feminas de familiis suis sarracenis, necessitate compulsi, et maxime qui eos obligant nec credunt se posse sufficere ad redemptionem eorum. Contingit autem multoties, quod taliter obligati et maxime pueri uel puelle fiunt postmodum sarraceni et si postea repetuntur non redduntur." Cited from Tolan, "Ramon de Penyafort's," accessed January 30, 2018, https://hal.archives-ouvertes.fr/hal-00761257.

18 Mounira Chapoutut-Ramadi, “Tunis," in Grandes villes méditerranéennes du monde musulman médiéval, ed. Jean-Claude Garcin (Rome, 2000), 241; Mohamed Tahar Mansouri, "Vie portuaire à Tunis au Bas Moyen Âge (XII-XVe siècle)," in Tunis, cité de la mer, ed. Alia Baccar-Bournaz (Tunis, 1999), 143-56, esp. 145-47. 
err against the articles of the faith, denying that Christ is God and Son of God, since they deny his Incarnation and Passion, we ask if the fathers, mothers, or other relatives of such people, or other people may communicate with them. Many of these people, when they converted, were ignorant of the articles of the faith; some were taken captive as infants; others converted due to a certain negligence. It seems to us that they cannot easily abstain from frequenting the above-mentioned people, either because they love them according to the flesh, as their children, or because they receive food from them.

We respond: they may communicate with them, either in order to correct them or out of necessity, and may receive food from them when they are in need, especially their relatives and other people connected with them. ${ }^{19}$

This passage shows that the friars and the pope were worried about apostasy, which in Europe would entail severe punishments like confiscation of assets or execution. Of course, they cannot threaten the apostates in Islamic territory with any retribution, even spiritual. According to Gratian's Decretum, if they have left the church, they cannot be excommunicated. ${ }^{20}$

Since there was nothing they could do about the apostates (except trying to persuade them to convert back to Christianity), they were concerned above all about members of their circle who did not convert to Islam. In the Decretum, associating with heretics was prohibited to all, except for clerics who sought to bring them back to the faith. The friars knew that if they tried to prohibit the Christians in Tūnis from seeing their close friends, this ban would have little effect, except perhaps to push other Christians to apostasy too. They knew these Christians could not avoid their Muslim parents, "both because they love them as their children and because they receive food from them." ${ }^{21}$ The pope responded that they could see these Muslims "causa correctionis vel necessitates"-in other words, in order to bring them back to the church or for material needs. Raymond and Gregory classified Islam as heresy from a legal point of view. This coincided with the contemporary theological consideration about Islam, in particular the works of Latin polemicists against Islam in the twelfth and thirteenth centuries. ${ }^{22}$ In

19 "Il y a certains individus qui étaient chrétiens et ensuite se sont fait Sarrasins, certains étant enfants, d'autres étant déjà adultes; certains sont libres, d'autres captifs. Puisqu'ils pêchent tous contre les articles de la foi, niant que le Christ soit Dieu et Fils de Dieu, déniant aussi son Incarnation et sa Passion, nous demandons si les parents de ces personnes ou d'autres membres de leur famille ou d'autres personnes peuvent communiquer avec eux. Certains ignoraient les articles de la foi [chrétienne] quand ils se sont faits Sarrasins, d'autres étaient captifs dès leur enfance, d'autres [se sont convertis] à cause d'une certaine négligence. Et nous ne voyons pas comment [leurs parents chrétiens] peuvent se passer de garder contact avec eux, soit parce qu'ils les aiment comme leurs enfants, soit parce qu'ils reçoivent d'eux la nourriture. Nous répondons: ils peuvent communiquer avec eux pour les corriger ou pour nécessité et recevoir d'eux la nourriture quand cela est nécessaire, surtout leurs parents et d'autres personnes associées." Cited from Tolan, Les relations entre les pays d'Islam et le monde latin, 165.

20 In Corpus iuris canonici, ed. E. Friedberg and E. Richter, 2 vols. (Graz, 1955-95), 2:50-92 (C.24 q.1 cc.4-5). See also Anders Winroth, The Making of Gratian's Decretum (Cambridge, 2000).

$2 \mathbf{I}$ "Soit parce qu'ils reçoivent d'eux la nourriture." Cited from Tolan, Les relations entre les pays d'Islam et le monde latin, 165.

22 John Tolan, Saracens (New York, 2002), 135-274 (chaps. 6-11).

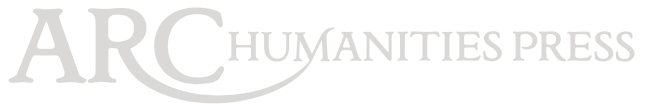


Raymond's Summa de Paenitentia, he asserts that Christians should not fraternize with Jews or Saracens, except for the preachers who go to terram eorum to preach to them about Christ. ${ }^{23}$ In this case, they could recognize the particular situation of the apostate families and soften this ban for them.

Even more difficult perhaps was the problem of apostasy within a couple. Raymond addressed the problem of mixed marriages in the second question in the Responsione, and later again in his work De matrimonio (probably composed between 1235 and 1240). ${ }^{24}$ Since, the marriage between a Christian and a non-Christian was not legal anyway, the question was to know what to do if a member of a Christian couple "fell into heresy" (labatur in haeresim) converting to Islam (again treated as heresy). In the Decretum, Gratian follows previous ecclesiastical legislation forbidding any marriage between Christians and non-Christians with some exceptions for cases of conversion. Case number twenty-eight in the Decretum is about an infidel husband who converts to Christianity, but whose wife remains infidel. Gratian affirms that new Christians can part from their infidel husband or wife, but he or she can also stay married. The main thing is to know if the Christian member of the couple can stay married to the infidel spouse without "offending God" (contumelia creatoris). According to the Decretum (C.28 q.2 c.2), when the infidel spouse hates Christianity and insults the Creator, the other partner can not only leave him or her, but can also remarry. Divorce is forbidden in the Bible, while the annulment of marriage was authorized only in particular situations, like consanguinity or as a result of adultery by one member of the couple. The Decretum affirms that "contumelia creatoris" represents a kind of spiritual adultery, indeed much worse than the physical variety, and therefore would be a matter of separation and annulment of the marriage. In 1235, Raymond and the pope applied the case of Gratian to the conversion of a member of an infidel couple to Christianity or vice versa, where a member of a Christian couple converted to Islam. In doing so, Raymond and the pope showed a certain flexibility and ease of innovation, adapting the principles of canon law to the particular situation of the Christians in Tünis. To do otherwise, as they knew, would only make the Christians' lives more difficult and more susceptible to apostasy.

The fatwa of Al-Mazari and the responsiones of Ramon show that jurists in the Middle Ages were able to react realistically and pragmatically, adapting the constraints of

23 Ramon de Penyafort, Summa de Paenitentia, Liber I, titulus IV, ed. Javier Ochoa Sanz and Luís Díez García (Rome, 1976), 2:308-17 (cols.); about the "fraternization" and the sharing of meals with Jews and Muslims in Canon Law Commentaires: David M. Freidenreich, "Sharing Meals with Non-Christians in Canon Law Commentaries, ca. 1160-1260. A Case Study in Legal Development," Medieval Encounters 14, no. 1 (2008): 41-77.

24 Ramon de Penyafort, Summa de Matrimonio, titulus X, "de dispari cultu", ed. Javier Ochoa Sanz and Luís Díez García, (Rome, 1976), 3:951-55 (cols.). To read the English translation of this treatise, see Raymond of Penyafort, Summa on Marriage, ed. Pierre J. Payer (Toronto, 2005). About this treatise, see Giovanni Minnucci, "Istituti di diritto precessurale nella Summa de poenitentia et matrimonio di san Raimondo di Penyafort," in Magister Raimundus. Atti del convegno per il IV centenario della canonizzazione di San Raimondo de Penyafort (1601-2001), ed. Carlo Longo (Rome, 2002), 87-109; and Ignacio Pérez de Heredia, "La Summa de Matrimonio de san Raimundo de Peñafort," in Magister Raimundus. Atti del convegno per il IV centenario della canonizzazione di San Raimondo de Penyafort (1601-2001), ed. Carlo Longo (Rome, 2002), 111-64. 
religious law (apparently inflexible) to the specific needs of their flock. To avoid the trap of essentialism, which leads us too often to see interreligious relations in the Middle Ages as a permanent conflict or as an irenic coexistence, we must look as we have done here at the concrete manifestations of regular interactions between communities and legal texts that tried to supervise them. 